\title{
STUDI PEMBUATAN KOMPOS PADAT DARI SAMPAH DAUN KERING TPST UNDIP DENGAN VARIASI BAHAN MIKROORGANISME LOKAL (MOL) DAUN
}

\author{
Mochtar Hadiwidodo $\left.{ }^{1, *}\right)$, Endro Sutrisno ${ }^{1}$, Dwi Siwi Handayani ${ }^{1}$, Masyitha \\ Putri Febriani $^{1}$
}

$\left.{ }^{1}\right)$ Departemen Teknik Lingkungan, Fakultas Teknik, Universitas Diponegoro, Jl. Prof. Soedarto, $\mathrm{SH}$, Kampus Undip Tembalang, Semarang, Indonesia 50275

e-mail :mch323@yahoo.com

\begin{abstract}
Abstrak
Tempat Pengolahan Sampah Terpadu Universitas Diponegoro (TPST Undip) merupakan sarana pengelolaan sampah mandiri yang dibangun pada tahun 2015 oleh pihak institusi Universitas Diponegoro. TPST Undip melakukan kegiatan pengelolaan sampah mulai dari pengangkutan hingga pengolahan sampah untuk wilayah pelayanan yang mencakup seluruh area yang ada di kampus Undip. Pihak TPST Undip sudah melakukan upaya untuk mengolah timbulan sampah tersebut, yaitu dengan melakukan komposting untuk sampah organik biodegradable dan melakukan recycle untuk sampah anorganik. Pengomposan tersebut dilakukan selama 3 - 5 minggu dengan menggunakan bantuan aktivator EM4. Dalam penelitian ini, akan dibuat bioaktivator berupa larutan mikroorganisme lokal (MOL) dari berbagai macam daun yang mudah didapatkan di lingkungan sekitar kampus, seperti daun ketapang (Terminalia catappa), daun angsana (Pterocarpus indicus) dan daun mahoni (Switenia mahagony). Bioaktivator ini akan menggantikan aktivator komersial EM4 untuk digunakan dalam pengomposan sampah daun kering. Proses pengomposan dilakukan secara aerobik dengan bak bersekat dan dilakukan selama 28 hari. Hasilnya kandungan unsur hara makro yaitu COrganik, $\mathrm{N}$-Total, dan K-Total dalam kompos ini telah memenuhi standar kualitas kompos di Indonesia yang diatur dalam SNI 19-7030-2004.
\end{abstract}

Kata kunci: sampah daun, MOL, kompos

\begin{abstract}
Integrated Waste Processing place University of Diponegoro (TPST Undip) is an independent waste management facility built in 2015 by the institution the University of Diponegoro. TPST Undip waste management activities ranging from transport to garbage processing service for the region that covers the entire area that is on the campus of Undip. Party TPST Undip has already made efforts to cultivate the waste timbulan, i.e. by doing komposting for organic waste is biodegradable and inorganic garbage recycle to do. Composting is done for $3-5$ weeks by using the help of Activator EM4. In this study, will be made in the form of a solution of bioaktivator local microorganisms (MOL) from a wide variety of leaves that are easily obtained in the neighborhood surrounding the campus, such as the leaves of ketapang (Terminalia catappa), leaf angsana (Pterocarpus indicus) and leaf Mahogany (Switenia mahagony). Bioaktivator will replace commercial EM4 activator for use in composting bins of dried leaves. The process of aerobic composting is carried out with bersekat and done for 28 days. The result of macro nutrient elements content i.e. C-organic and N-Total, K-Total in the compost has complied with standards of quality compost in Indonesia which is set in the SNI 19-7030-2004.
\end{abstract}

Keywords : leaf waste,MOL,compost

\section{Pendahuluan}

Sampah merupakan permasalahan yang umum yang dihadapi oleh berbagai sektor termasuk sektor institusi pendidikan seperti Universitas Diponegoro. Adanya berbagai macam jenis kegiatan di kampus dan peningkatan jumlah mahasiswa setiap tahunnya menyebabkan munculnya persoalan dalam upaya penanganan persampahan. Sejak tahun 2015, pihak Universitas Diponegoro membangun Tempat Pengolahan Sampah Terpadu (TPST Undip) yang difungsikan sebagai sarana pengelolaan 
sampah secara mandiri yang melayani seluruh area kampus Undip, mulai dari kegiatan pengangkutan sampah di tiap - tiap area kampus hingga pengolahan sampah yang dilakukan terpusat di area TPST Undip sendiri. Tim Teknis TPST Undip menyebutkan bahwa pada tahun 2015 jumlah timbulan sampah sebesar 11,82 m3/hari dengan komposisi $43,68 \%$ merupakan sampah organik dan 56,32\% merupakan sampah anorganik. Sehingga terdapat 4.307 m3 sampah per tahun yang harus diolah. Pihak TPST Undip sudah melakukan upaya untuk mengolah timbulan sampah tersebut, yaitu dengan melakukan komposting untuk sampah organik biodegradable dan melakukan recycle untuk sampah anorganik.

Menurut Anggarini (2015), komposisi timbulan sampah tertinggi untuk sampah organik di Universitas Diponegoro adalah sampah daun dengan berat $321,94 \mathrm{~kg} /$ tahun atau sekitar $38,12 \%$. Jumlah ini lebih besar dibandingkan dengan sampah organik lainnya seperti sampah sisa makanan sejumlah $172,95 \mathrm{~kg} /$ tahun $(20,48 \%)$. Oleh karena itu, pengomposan sampah organik yang dilakukan di TPST Undip sebagian besar berupa sampah daun kering. Kegiatan pengomposan berlangsung secara konvensional selama 3 - 5 minggu dalam bak - bak bersekat dengan ukuran 2 m3 sejumlah 23 bak. Sampah daun kering dilakukan pencacahan terlebih dahulu sebelum dikomposkan dalam bak, kemudian diberikan larutan EM4 sebagai aktivator dan secara rutin akan dilakukan pembalikan.

Dalam pembuatan kompos, aktivator digunakan untuk mempercepat proses kematangan kompos. Selain menggunakan aktivator komersial, dapat digunakan bioaktivator dengan memanfaatkan mikroorganisme lokal (MOL). Larutan MOL merupakan hasil fermentasi yang dapat dibuat dari berbagai bahan yang tersedia di lingkungan sekitar kita. Larutan ini mengandung mikroorganisme yang dapat merombak bahan organik, merangsang pertumbuhan tanaman dan sebagai agen pengendali hama penyakit tanaman (Sutari, 2009). Menurut Purwasasmita (2009), larutan MOL dapat dibuat dengan cara sederhana, misalnya dengan memanfaatkan limbah yang ada disekitar lingkungan kita. Komponen utama yang harus dipenuhi dalam bahan pembuatan MOL adalah karbohidrat, glukosa dan sumber mikroorganisme.

Dalam penelitian ini, akan dilakukan pembuatan kompos padat dari sampah daun kering TPST Undip dengan menggunakan bioaktivator mikroorganisme lokal (MOL) yang terbuat dari campuran jenis dedaunan sebagai sumber mikroorganismenya, antara lain daun ketapang (Terminalia catappa), daun angsana (Pterocarpus indicus) dan daun mahoni (Switenia mahagony). Sedangkan sumber karbohidrat dan glukosa menggunakan air tepung beras dan tetes tebu (molase). Larutan MOL ini akan difermentasi selama 14 hari sebelum ditambahkan ke bahan kompos.

Penelitian ini hanya terbatas pada pembuatan kompos padat dari sampah daun TPST Undip dengan bantuan bioaktivator MOL Daun yang akan dilakukan selama 28 hari dengan proses pengomposan secara aerobik. Tujuannya untuk mengetahui pengaruh penggunaan larutan $\mathrm{MOL}$ daun tersebut terhadap kandungan unsur hara makro (C, N, P, K) kompos padat yang dihasilkan dan mengetahui waktu optimum kematangan kompos.

\section{Metodologi Penelitian}

Penelitian dilaksanakan selama 42 hari di TPST Undip. Jenis penelitian ini bersifat eksperimental laboratorium. Penelitian ini dilakukan dalam 2 tahapan, sebagai berikut :

1. Tahapan pertama

Melakukan proses pembuatan bioaktivator larutan MOL dengan menggunakan 3 jenis daun dari tanaman yang banyak terdapat di sekitar kampus Undip yaitu daun ketapang (Terminalia catappa), daun mahoni (Switenia mahagoni), dan daun angsana (Pterocarpus indicus). Berikut langkah kerja dalam pembuatan larutan MOL daun :

a) Menyiapkan alat, seperti gelas ukur, jerigen, botol bekas, selang bening, blender, pisau, dan lem tembak.

b) Menyiapkan bahan dengan komposisi sebagai berikut :

MOL 1 : 300 gram daun ketapang + 300 gram daun mahoni +100 gram tepung beras $+2 \mathrm{~L}$ air + $200 \mathrm{~mL}$ molase

MOL 2 : 300 gram daun ketapang + 300 gram daun angsana +100 gram tepung beras $+2 \mathrm{~L}$ air + $200 \mathrm{~mL}$ molase

MOL 3 : 200 gram daun ketapang + 200 gram daun mahoni +200 gram daun angsana +100 gram tepung beras $+2 \mathrm{~L}$ air $+200 \mathrm{~mL}$ molase

c) Melarutkan 100 gram tepung beras ke dalam $2 \mathrm{~L}$ air sumur untuk masing - masing variasi larutan MOL

d) Menghaluskan $600 \mathrm{gr}$ campuran daun sesuai variasi yang ditentukan dengan blender, sebelumnya lebih baik daun dipotong menjadi ukuran yang lebih kecil agar lebih mudah diblender 
e) Memasukkan campuran daun yang telah halus dan larutan tepung beras ke dalam jerigen, kemudian ditambahkan $200 \mathrm{~mL}$ molase

f) Mengaduk semua bahan menggunakan batang kayu atau kocok jerigen agar semua bahan tercampur rata

g) Menutup jerigen dengan rapat agar tidak terdapat hewan/ material lain yang masuk ke dalam campuran bahan, sebelumnya tutup jerigen disambungkan ke botol bekas 1,5L yang telah terisi air setengah bagian menggunakan selang bening, hal ini bertujuan untuk menampung pelepasan udara dari proses fermentasi bahan didalam jerigen selama masa fermentasi sehingga jerigen tidak akan meledak

h) Masa fermentasi pembuatan larutan MOL ini dilakukan selama 14 hari didalam ruang tertutup dan tidak terpapar sinar matahari secara langsung (jerigen dapat diletakkan di dalam ruangan dan diberi penutup/ dimasukkan ke dalam kotak kardus)

i) Setelah hari ke - 14, jerigen dapat dibuka dan kemudian isinya disaring/ diperas untuk mendapatkan larutan MOL hasil fermentasi yang akan digunakan sebagai bioaktivator dalam pengomposan sampah daun kering di TPST

j) Pengujian sampel larutan MOL akan dilakukan di laboratorium Teknik Lingkungan untuk mengetahui kandungan $\mathrm{C}$ - Organik, N - Total, P - Total dan K - Total, serta pengujian TPC (Total Plate Count) di Laboratorium Terpadu Undip.

2. Tahapan kedua

Melakukan pengomposan sampah daun kering dengan menggunakan bioaktivator larutan MOL yang telah dibuat dalam tahap 1. Langkah kerja pembuatan kompos sebagai berikut :

a) Menyiapkan alat, seperti bak komposting, mesin pencacah daun, gelas ukur, sekop, timbangan, ember dan sprayer. Reaktor komposting terdiri dari 4 kompartmen dengan masing - masing ukuran panjang, lebar dan tinggi adalah $50 \mathrm{~cm}, 100 \mathrm{~cm}$, dan $25 \mathrm{~cm}$.

b) Menyiapkan bahan pengomposan dengan komposisi sebagai berikut :

: 7 kg sampah daun +7 liter air

: $7 \mathrm{~kg}$ sampah daun +7 liter air $(840 \mathrm{~mL}$ MOL 1 + 6,16 liter air)

: $7 \mathrm{~kg}$ sampah daun +7 liter air $(840 \mathrm{~mL}$ MOL $2+6,16$ liter air)

: $7 \mathrm{~kg}$ sampah daun +7 liter air $(840 \mathrm{~mL}$ MOL $3+6,16$ liter air)

b) Melakukan pencacahan sampah daun kering yang akan dikomposkan menggunakan mesin pencacah dan kemudian diletakkan pada masing - masing kompartmen

c) Melarutkan bioaktivator $\mathrm{MOL}$ dengan menggunakan air sumur (120 ml MOL/ 1 liter air/ $1 \mathrm{~kg}$ sampah) d) Menyemprotkan larutan MOL tersebut ke dalam tumpukan sampah daun sambil diaduk - aduk supaya penyemprotannya merata

e) Menutup bak pengomposan menggunakan terpal untuk menghindari adanya material lain yang masuk ke dalam bak pengomposan dan melindungi dari hujan

f) Pengomposan sampah daun kering tersebut dilakukan selama 28 hari dan setiap 3 hari sekali dilakukan pembalikan tumpukan kompos yang bertujuan untuk memberikan ketersediaan oksigen selama masa pengomposan

g) Memantau kondisi $\mathrm{pH}$ dan temperature selama masa pengomposan setiap 1 hari sekali serta dilakukan pencatatan

h) Mengambil sampel kompos pada hari ke $0,7,14,21$, dan 28 untuk dilakukan pengujian di laboratorium Teknik Lingkungan untuk mengetahui kandungan C - Organik, N Total, P - Total dan K - Total

i) Setelah hari ke - 28, tumpukan kompos dapat dibuka dan dikeringkan secara alami dengan sinar matahari, kemudian dapat diaplikasikan pada tanaman

\section{Hasil dan Pembahasan}

Dalam penelitian ini, digunakan bioaktivator mikroorganisme lokal (MOL) yang terbuat dari campuran jenis dedaunan sebagai sumber mikroorganismenya, antara lain daun ketapang (Terminalia catappa), daun angsana (Pterocarpus indicus) dan daun mahoni (Switenia mahagony). Kandungan unsur hara makro MOL Daun tersebut terdapat dalam Tabel 1. sebagai berikut :

Tabel 1. Kandungan Unsur Makro MOL Daun

\begin{tabular}{clll}
\hline Parameter & MOL 1 & MOL 2 & MOL 3 \\
\hline $\mathbf{C ~ ( \% ) ~}$ & 30,926 & 35,513 & 33,926 \\
$\mathbf{N}(\%)$ & 0,954 & 1,340 & 0,603 \\
$\mathbf{P}(\%)$ & 0,039 & 0,043 & 0,047 \\
$\mathbf{K}(\%)$ & 6,664 & 6,684 & 8,506 \\
\hline
\end{tabular}

Berdasarkan tabel diatas tiga jenis variasi MOL Daun yang digunakan dalam proses pengomposan memiliki nilai C-Organik, NTotal, P-Total dan K-Total yang berbedabeda. Kandungan C-Organik dan N-Total nilai terbesar dimiliki oleh MOL 2 (KetapangAngsana) serta kandungan P-Total dan KTotal pada MOL 3 (Ketapang-MahoniAngsana).

Setelah dilakukan pembuatan ketiga jenis variasi MOL Daun tersebut, kemudian dilanjutkan dengan proses pengomposan sampah daun kering selama 28 hari secara aerobik. Kondisi yang diamati selama proses pengomposan adalah temperature, $\mathrm{pH}$ dan kadar air kompos.

Temperature selama proses pengomposan mengindikasikan adanya 
panas yang dilepaskan oleh mikroorganisme sebagai hasil dari reaksi oksidasi (Anjangsari, 2010). Hasil pengukuran temperature dengan berbagai variasi penggunaan MOL Daun dapat dilihat pada Gambar 2 sebagai berikut :

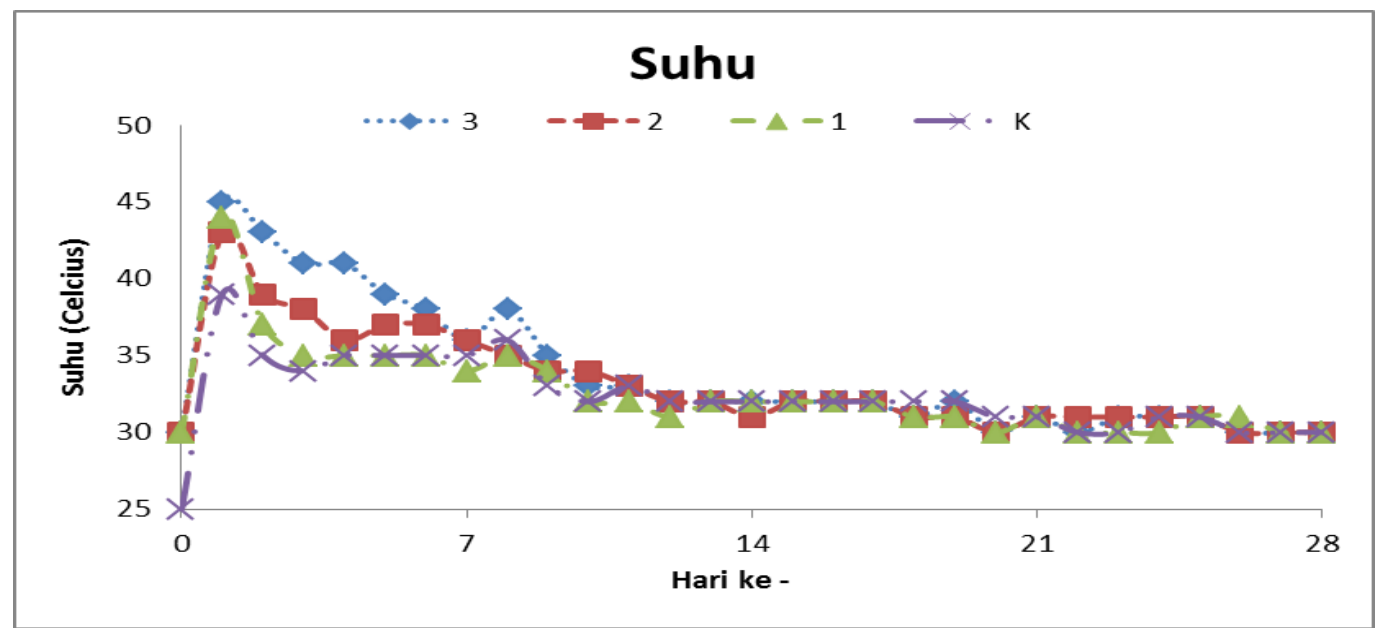

Gambar 1. Pengukuran Temperature Kompos

Berdasarkan grafik diatas, dapat diketahui bahwa terjadi peningkatan temperature pada waktu awal pengomposan yaitu pada hari ke - 1. Sesuai dengan Hartutik dkk (2009) bahwa kenaikan temperature tersebut diakibatkan oleh aktivitas mikroorganisme dalam proses dekomposisi bahan organik. Nilai temperature puncak pada masing masing kompos yaitu $39^{\circ} \mathrm{C}$ untuk reaktor kontrol, $44^{\circ} \mathrm{C}$ untuk reaktor $1,43^{\circ} \mathrm{C}$ untuk reaktor 2 dan $45^{\circ} \mathrm{C}$ untuk reaktor 3 .
Temperature puncak pada semua variasi kompos hanya terjadi selama 1 hari dan berangsur - angsur mengalami penurunan mendekati temperature tanah.

$\mathrm{pH}$ dapat dijadikan sebagai indikator kehidupan mikroorganisme. Rentang $\mathrm{pH}$ tumpukan kompos sebaiknya dipertahankan berkisar antara 7-7,5 sesuai dengan $\mathrm{pH}$ yang dibutuhkan tanaman (Damanhuri dan Padmi, 2010).

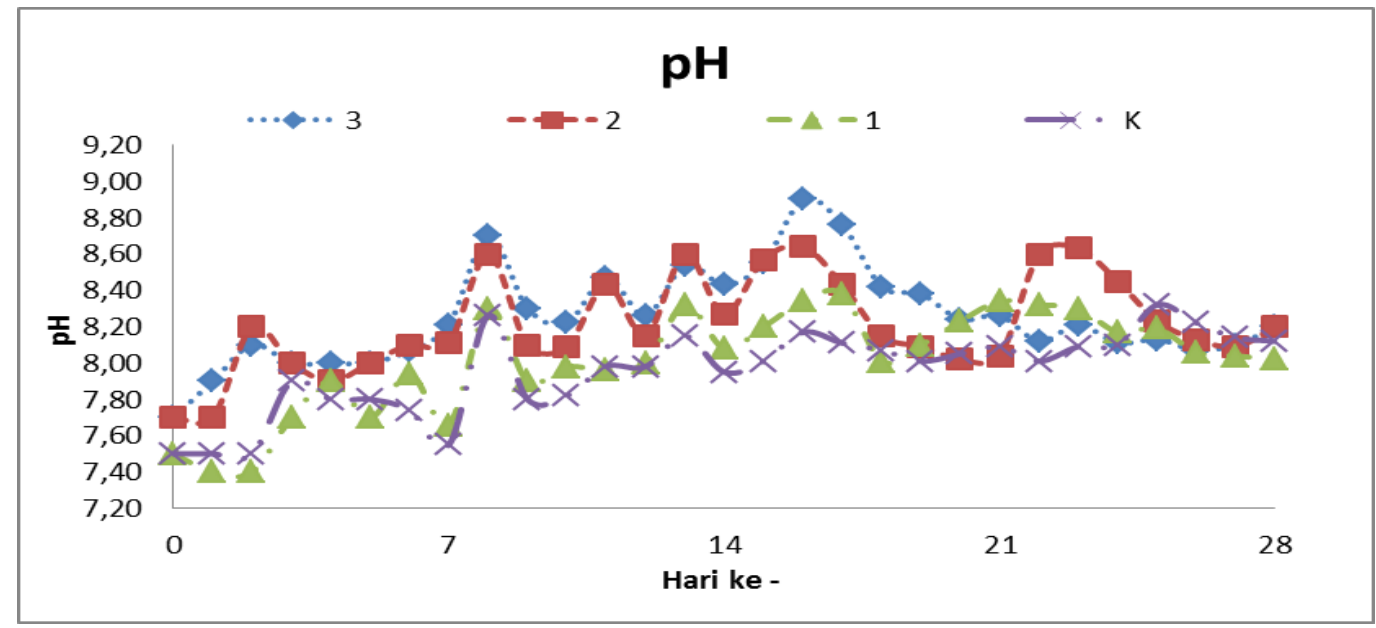

Gambar 2. Pengukuran pH Kompos

Dari grafik diatas $\mathrm{pH}$ awal semua reaktor pengomposan berada pada rentang 7,5-7,7 dan kemudian hingga pada hari ke-28 $\mathrm{pH}$ cenderung meningkat dalam keadaan basa dengan rentang 8,0-8,2. Menurut Tchobagnoglous et al (1993), keasaman kompos dipengaruhi oleh pembentukan asam organik dan kadar amonia. $\mathrm{pH}$ akan meningkat karena pembentukan amonia dan perkembangan populasi mikroba yang menggunakan asam organik sebagai substrat.

Sedangkan untuk kondisi kadar air selama proses pengomposan berlangsung nilai cenderung mengalami penurunan. Menurut Ayuningtyas (2009), penurunan kandungan air dalam pengomposan secara aerobik terjadi karena kandungan air dalam bahan kompos menguap akibat panas, pengadukan dan konsumsi mikroorganisme untuk mengkonversi protein menjadi unsur 
hara yang diperlukan tanaman. Nilai kadar air awal proses pengomposan berada pada rentang $66 \%-68 \%$ yang kemudian hingga

pada hari ke-28 nilai kadar air hanya mencapai rentang 62\%-66\%.

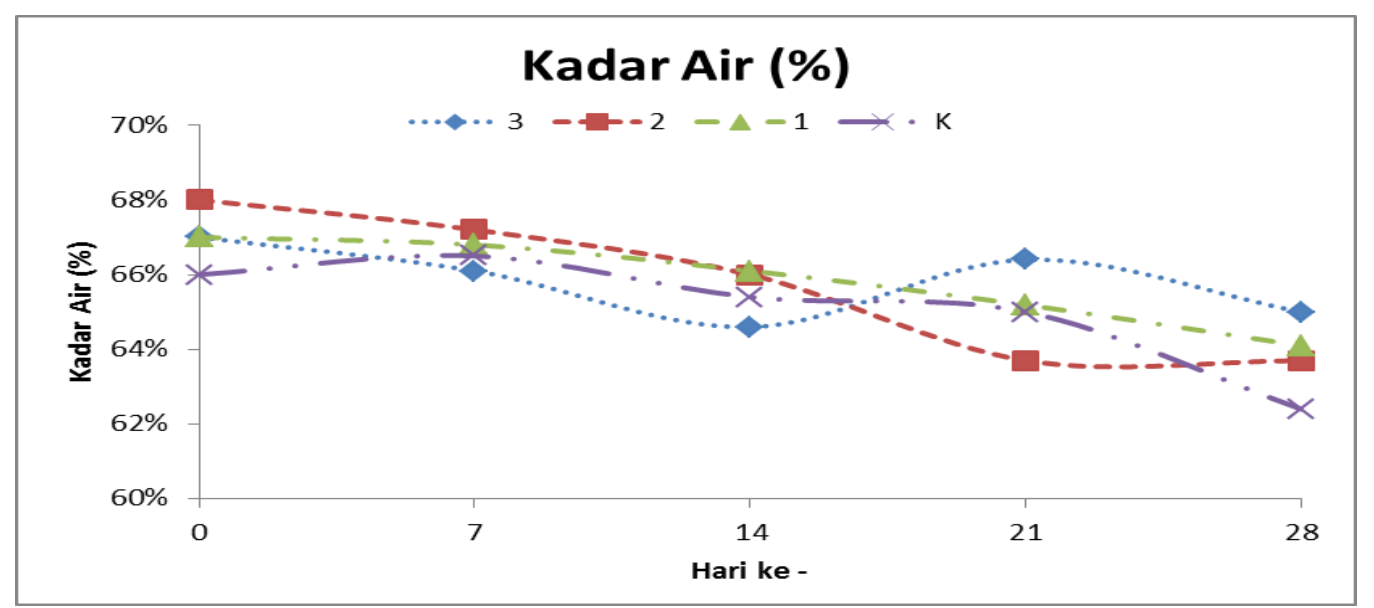

Gambar 3. Pengukuran Kadar Air Kompos

Unsur hara makro digunakan tanaman untuk membantu proses pertumbuhan. Unsur C-Organik, N-Total, P-Total, dan K-Total bisa diperoleh dengan menambahkan kompos ke tanaman. Hasil pengukuran kadar unsur hara makro selama proses pengomposan ditampilkan dalam Tabel 2 berikut.

Tabel 2. Hasil Pengukuran Unsur Hara Makro

\begin{tabular}{|c|c|c|c|c|c|}
\hline Parameter & $\mathrm{HO}$ & $\mathrm{H} 7$ & $\mathrm{H} 14$ & $\mathrm{H} 21$ & $\mathrm{H} 28$ \\
\hline \multicolumn{6}{|c|}{ C Organik (\%) } \\
\hline Kontrol & 26,32 & 23,09 & 23,17 & 25,73 & 23,48 \\
\hline Reaktor 1 & 27,01 & 23,52 & 22,28 & 24,01 & 21,11 \\
\hline Reaktor 2 & 28,43 & 23,18 & 24,06 & 24,76 & 22,04 \\
\hline Reaktor 3 & 28,54 & 23,29 & 24,19 & 23,27 & 22,36 \\
\hline \multicolumn{6}{|c|}{ N Total (\%) } \\
\hline Kontrol & 0,74 & 0,91 & 1,11 & 0,89 & 1,27 \\
\hline Reaktor 1 & 0,63 & 0,86 & 1,18 & 1,02 & 1,18 \\
\hline Reaktor 2 & 0,59 & 0,76 & 1,22 & 1,03 & 1,29 \\
\hline Reaktor 3 & 0,47 & 1,05 & 1,02 & 0,87 & 1,18 \\
\hline \multicolumn{6}{|c|}{ P Total (\%) } \\
\hline Kontrol & 0,027 & 0,024 & 0,034 & 0,023 & 0,026 \\
\hline Reaktor 1 & 0,029 & 0,036 & 0,024 & 0,021 & 0,023 \\
\hline Reaktor 2 & 0,031 & 0,025 & 0,027 & 0,018 & 0,025 \\
\hline Reaktor 3 & 0,032 & 0,026 & 0,027 & 0,016 & 0,018 \\
\hline \multicolumn{6}{|c|}{ K Total (\%) } \\
\hline Kontrol & 1,18 & 1,25 & 1,20 & 1,34 & 0,86 \\
\hline Reaktor 1 & 1,06 & 1,52 & 1,34 & 1,59 & 0,87 \\
\hline Reaktor 2 & 1,09 & 1,42 & 1,29 & 1,32 & 0,88 \\
\hline Reaktor 3 & 1,38 & 1,51 & 1,08 & 1,16 & 0,79 \\
\hline
\end{tabular}

Menurut Arlinda (2011), unsur karbon dimanfaatkan oleh mikroorganisme sebagai sumber energi selama proses dekomposisi bahan organik. Selama proses pengomposan, kadar C-organik untuk semua variasi kompos cenderung menurun dari awal hingga akhir pengomposan. Hal ini terjadi karena terjadi oksidasi senyawa karbon dalam kompos menjadi karbondioksida $\left(\mathrm{CO}_{2}\right)$. Kondisi ini dipengaruhi oleh suhu, $\mathrm{pH}$ dan kelembaban bahan kompos (Widadi, 2001). Di awal pengomposan, kadar C-organik berada pada rentang 26 - 29\%, sedangkan di akhir pengomposan kadar C-organik berada pada rentang $21-24 \%$. Hal tersebut memenuhi SNI 19-4030-2004 bahwa standar unsur karbon di dalam kompos matang sebesar 9,80-32\%.

Unsur nitrogen dibutuhkan tanaman untuk pembentukan asam amino, protein, klorofil, dan pembentukan enzim (Soeryoko, 2011). Kekurangan nitrogen dalam proses pengomposan dapat menyebabkan laju dekomposisi berjalan lebih lambat (Suswardany dkk, 2006). Dalam proses pengomposan, kadar nitrogen untuk semua variasi kompos mengalami peningkatan. Kadar nitrogen di awal berada pada rentang 0,47 - 0,74\%. Sedangkan di akhir proses pengomposan, kadar nitrogen meningkat pada rentang 1,18 - 1,29\%. Menurut Jannah (2003), kenaikan kadar N - Total dalam proses pengomposan diakibatkan oleh adanya penguraian protein menjadi asam amino oleh mikroorganisme yang kemudian asam amino mengalami amonifikasi menjadi ammonium yang selanjutnya dioksidasi menjadi nitrat. Kadar nitrogen kompos daun kering telah memenuhi standar unsur nitrogen untuk kompos matang menurut SNI 19-40302004 yaitu $>0,4 \%$.

Hardjowigeno (2003) menyampaikan bahwa kandungan fosfor digunakan untuk merangsang pertumbuhan tanaman, akar, pembentukan biji, dan pembelahan sel. Selama proses pengomposan, kadar P-total untuk semua variasi kompos mengalami fluktuasi dan cenderung turun dari awal hingga akhir pengomposan. Kadar P-total di akhir pengomposan cukup rendah, yaitu pada rentang 0,018 - 0,026\% di akhir proses pengomposan. Dalam SNI 19-4030-2004 kadar P-Total dalam kompos matang minimum adalah $0,1 \%$ sehingga dalam penelitian ini belum dihasilkan kompos 
dengan kadar P-Total yang mencukupi. Untuk meningkatkan kadar P-Total dapat dilakukan dengan penambahan bahan yang kaya akan kandungan pospor, seperti tepung tulang ikan.

Kadar kalium berguna untuk membantu pembentukan protein dan karbohidrat serta meningkatkan daya tahan tanaman (Sutedjo, 1995). Sama halnya dengan kadar P-total, untuk kadar K-total selama proses pengomposan juga mengalami kenaikan pada 3 minggu pertama dan kemudian mengalami penurunan untuk pengomposan pada hari ke28 sebesar 0,79-0,88\%. Walidaini (2016) menjelaskan bahwa selama proses pengomposan,kandungan kalium cenderung meningkat karena kalium digunakan oleh mikroorganisme sebagai katalisator, dengan adanya bakteri dan aktivitas bakteri akan mempengaruhi peningkatan kandungan kalium. Di dalam SNI 19-4030-2004 kandungan unsur kalian dalam kompos daun kering sudah memenuhi persyaratan yaitu minimum sebesar $0,2 \%$.

\section{Kesimpulan}

Mikroorganisme lokal (MOL) yang dibuat dengan campuran berbagai jenis daun (Ketapang, Mahoni, Angsana) memiliki nilai C-Organik, N-Total, P-Total dan K-Total serta dapat digunakan sebagai alternatif penggunaan aktivator dalam proses pengomposan. Hasil kandungan unsur hara makro yaitu C-Organik, N-Total, dan K-Total dalam kompos daun kering yang dibuat dengan menggunakan aktivator MOL Daun telah memenuhi standar kualitas kompos di Indonesia yang diatur dalam SNI 19-70302004 tentang Spesifikasi Kompos dari Sampah Organik Domestik. Sedangkan untuk kadar P-Total kompos daun kering masih terlalu rendah dari standar tersebut.

\section{Ucapan Terima Kasih}

Ucapan terimasih kepada pihak TPST Universitas Diponegoro sebagai tempat studi, Laboratorium Teknik Lingkungan yang telah membantu pengujian parameter, dan penyedia dana, serta pihak - pihak lain yang terlibat dalam penelitian ini.

\section{Daftar Pustaka}

Anggarini, Riani. 2015. Perencanaan Pemindahan dan Pengangkutan Sampah Kampus Universitas Diponegoro Tembalang Semarang. Semarang : Teknik Lingkungan
Fakultas Teknik Universitas Diponegoro.

Anjangsari, Eki. 2010. Vermikomposting Campuran Feses Gajah (Elephas maximus sumatrensis) dan Serasah. Institut Teknologi Sepuluh Nopember. Surabaya.

Arifin, Z., dan Amik K. 2008. Pertanian Organik Menuju Pertanian Berkelanjutan. Bayumedia Publishing. Malang.

Arlinda. 2011. Study of Comparative Chemical Quality Of Compost Made From Oil Palm Bunches With Activator Of Activated Sludge Coca Cola, Cocomas And Bokashi Compost. Institut Pertanian Bogor.

Ayuningtias, Dyah Nurhati. 2009. Pengaruh Ketersediaan Oksigen dan Sistem Aerasi terhadap Laju Proses Pengomposan dan Kualitas Kompos Berbahan Baku Limbah Pencucian Biji Kakao Terfermentasi, Serasah Daun, dan Kotoran Sapi. Bogor: Institut Pertanian Bogor.

Chen L. A., Moore M. E., de Haro-Murti. 2012. On-Farm Composting Management. University of Idaho Extension.

Damanhuri, E dan Padmi. 2010. Diktat Kuliah Pengelolaan Sampah. Institut Teknologi Bandung. Bandung.

Damanhuri dan Padmi, 2016. Pengelolaan Sampah Terpadu. Penerbit ITB. Bandung.

Gusmailina. 2010. Pengaruh Arang Kompos Bioaktif Terhadap Pertumbuhan Anakan Bulian (Eusyderoxylon zwageri) dan Gaharu (Aquilaria malaccensis). Bogor: Pusat Litbang Hasil Hutan.

Hardjowigeno,S. 2003. LImu Tanah. Akademika Presindo, Jakarta.

Hartutik, Sri., Sriatun., dan Taslimah. 2009. Pembuatan Pupuk Kompos dari Limbah Bunga Kenanga dan Pengaruh Persentase terhadap Ketersediaan Nitrogen Tanah.

Jannah, M. 2003. Evaluasi Kualitas Kompos dari Berbagai Kota sebagai Dasar dalam Pembuatan SOP (Standard Operating Procedure) Pengomposan. (Skripsi). Bogor: Institut Pertanian Bogor.

Mehl, Jessica A. 2008. Pathogen Destruction and Anaerobic Decomposition in Composting Latrines: A Study from Rural Panama. Michgan Technological University.

Mulyani, H. 2007. Pengembangan Model Pengomposan di RW $X$ Paten Gunung, Kelurahan Rejowinangun 
Selatan. Kota Magelang. Laporan Penelitian Akademik Teknik Tirta Wiyata.

Mulyani, H. 2014. Optimasi Perancangan Model Pengomposan. Trans Info Media. Jakarta.

Pattnaik, S. and M.V. Reddy. 2010. Nutrient Status of Vermicompost of Urban Green Waste Processed by Three Earthworm Species Eisenia foetida Eudrilus eugeniae, and Perionyx excavates. Applied and Environmental Soil Science. Volume 2010. Article ID 967526. 13 pages.

Purwasasmita M, Kurnia K. 2009. Mikroorganisme Lokal sebagai Pemicu Siklus Kehidupan dalam Bioreaktor Tanaman. Seminar Nasional Teknik Kimia IndonesiaSNTKI. Bandung.

Raabe, R, D. 2016. The Rapid Composting Method. University of California. California.

Soeryoko, Hery. 2011. Kiat Pintar Memproduksi Kompos. Lily Publisher. Yogyakarta.

Standar Nasional Indonesia 19-2454-2002 tentang Tata Cara Teknik Operasional Pengelolaan Sampah Perkotaan.

Standar Nasional Indonesia 19-7030-2004 Tentang Spesifikasi Kompos Dari Sampah Organik Domestik.

Sucipto, C.D. 2012. Teknologi Pengolahan Daur Ulang Sampah. Yogyakarta : Gosyen Publising.

Susanto, A. 2016. Studi Pengolahan Sampah Daun di Kampus Univeritas Hasanudin. Program Studi Teknik Lingkungan Jurusan Teknik Sipil Universitas Hasanudin.
Sutari, N.W.S. 2009. Pengujian KualitasBioUrine Hasil Fermentasi Dengan Mikroba yang Berasal dari BahanTanaman terhadap Pertumbuhan dan Hasil Tanaman Sawi (Brassica JunceaL ). Tesis. Program Pasca SarjanaUniversitas Udayana, Denpasar

Soeryoko, Hery. 2011. Kiat Pintar Memproduksi Kompos. Lily Publisher. Yogyakarta.

Suswardany, D.L., Ambarwati, dan Y. Kusumawati. 2006. Peran Effective Microorganism-4 (EM-4) dalam Meningkatkan Kualitas Kimia Kompos Ampas Tahu. Surakarta: Universitas Muhammadiyah Surakarta

Sutedjo, Mul Mulyani. 1995. Pupuk dan Cara Pemupukan. PT. Rineka Cipta, Jakarta.

Undang-Undang Nomor 18 Tahun 2008 tentang Pengelolaan Sampah.

Widadi. 2001. Pengaruh Variasi Dosis Starter EM4 Terhadap Terhadap Kompos Sekam (Bokashi) Studi Kasus di Petani Organik Klaten Jawa Tengah. Yogyakarta. : Sekolah Tinggi Teknik Lingkungan Yogyakarta

Widarti, B.N. dkk. 2015. Pengaruh Rasio C/N Bahan Baku pada Pembuatan Kompos dari Kubis dan Kulit Pisang. Samarinda : Teknik Lingkungan Unmul.

Walidaini, R. D. A. 2016. Pengaruh Penambahan Pupuk Urea dalam Pengomposan Sampah organik secara Aerobik menjadi Kompos Matang dan Stabil Diperkaya. Semarang : Universitas Diponegoro 